\title{
Traditional foods and beverages in Eastern Tigray of Ethiopia
}

\author{
Nigussie Seboka Tadesse* (D, Girum Faris Beyene, Tesfaye Bekele Hordofa and Ashenafi Ayenew Hailu
}

\begin{abstract}
Ethiopia is a multiethnic country with diverse cultural practices to prepare foods and beverages having significant contributions in socioeconomic development. Contrary, comprehensive documentation of the products, associated knowledge, and their sociocultural roles is incomplete. In this survey, thirteen typical traditional foods (two fermented and eleven non-fermented) and five traditional beverages (four fermented and one non-fermented) were listed referring the local community of East Tigray. The noted traditional foods/beverages are known for their social and cultural values in the local community, and they are exercised following celebrity events. They are prepared often from barley (Hordeum vulgare), peas (Pisum sativum), wheat (Triticum aestivum), buckthorn (Rhamnus prinoides), maize (Zea mays), sorghum (Sorghum bicolor), and teff (Eragrostis tef). Some of the dishes/drinks such as Ambasha, Ebist, Gaa't, Tihelo, Beso, Zikizuko, Abaekah, Duqua, Suwa, Mes, and Tahetah are well-acknowledged for their health and economic benefits. Others, like Birkuta and sola, are used to survive a long journey and looming drought. To conclude, this article presents a list of traditional foods and beverages which are potentially applicable in modern food or beverage industries and can contribute for global healthy diet.
\end{abstract}

Keywords: Ethiopian traditional foods, Traditional beverages, Cuisine arts, Tigray, Erob

\section{Introduction}

The Convention on Biological Diversity states traditional knowledge (TK) as knowledge, innovations, and practices of indigenous communities. TK is developed through experiences, associated with culture and biological resources, conserved in a traditional context, and learned through observation or/and practices [1]. Proper utilization of TK can help to address food security, human and animal health problems, and education and natural resource management issues [2].

Traditional foods or beverages are natural diets or drinks which nourished our ancestors throughout the evolutionary history of human particularly in the prehistory of the industrialization of food or beverage. In Ethiopia, the history of traditional foods or beverages is dating to the early of crop domestication and agriculture innovation, and it is linked to celebrations such as

\footnotetext{
* Correspondence: nigussie88@gmail.com

Genetic Resources Access and Benefit Sharing Directorate, Ethiopian Biodiversity Institute, P.O. Box 30726, Addis Ababa, Ethiopia
}

holidays, festivals, social gatherings, funeral, to honor guests, and special occasions [3, 4]. Tigray has long been recognized as an important center of plant domestication and agricultural innovation. Archaeological evidences from the region suggest food producing societies were living in the region before the third millennia $\mathrm{BC}$ [5]. Geomorphologic, palynological, and archaeological studies in the region also provide the dynamic relationships between human and environment on the plateau during the Holocene [5]. Traditional foods or drinks have been serving for multipurpose in the country for a long time: nutrition, ensuring food security, medication, and socio-economic benefits. For example, during "Zamana Mesafint" (1769-1855) traditional foods and beverages were prepared targeting specific occasions: $T e j$ to honor royalty and nobility and Besso and Chekko for military campaign [6]. Nowadays, Besso and Chekko are popular public foods that people carry with them (commonly called Sinq) to ensure food security during longdistance travels, and Tej is a famous public drink available throughout the country. Genfo (porridge), which is

(c) The Author(s). 2020 Open Access This article is licensed under a Creative Commons Attribution 4.0 International License, which permits use, sharing, adaptation, distribution and reproduction in any medium or format, as long as you give appropriate credit to the original author(s) and the source, provide a link to the Creative Commons licence, and indicate if changes were made. The images or other third party material in this article are included in the article's Creative Commons licence, unless indicated otherwise in a credit line to the material. If material is not included in the article's Creative Commons licence and your intended use is not permitted by statutory regulation or exceeds the permitted use, you will need to obtain permission directly from the copyright holder. To view a copy of this licence, visit http://creativecommons.org/licenses/by/4.0/. 
prepared from oat (Avena sativa), is a diet of women during postpartum and individuals recuperating from all kinds of illnesses $[6,7]$. In north and central high lands of Ethiopia, Tej, Tela, Ambasha, Tihelo, Injera, and other unique foods/beverages are still predominantly in use, and the culinary art has been inherited for centuries, although the effort to document and advance is very rare $[8,9]$.

The highland Ethiopian agricultural complex is viewed as a combination of indigenous food/beverage crops and a number of endemic varieties including teff (Eragrostis teff), noog (Guizotia abyssinica), finger millet (Eleusine coracana), wheat (Triticum aestivum), barley (Hordeum vulgare), chick pea (Cicer arietinum), lentil (Lens culinaris), and fava bean (Vicia faba L.) [5]. This suggests a long and complex history of local cultivation and genetic diversification in the region. However, our understanding of the diversity of food and beverage production in this area is poor. Thus, researching the field is vital to conserve and advance the knowledge, protect from unethical patents, and promote the use to enhance global food security [10]. This survey aimed to document typical traditional foods/beverages, preparation practices, and their sociocultural roles in East Tigray of Ethiopia.

\section{Materials and methods \\ Study population}

Tigray National Regional State is the northernmost of Ethiopia located at $12^{\circ} 12^{\prime}$ to $14^{\circ} 32^{\prime} \mathrm{N}$ latitude and $36^{\circ}$ $30^{\prime}$ to $40^{\circ} 30^{\prime} \mathrm{E}$ longitude. Tigray is one of the 85 ethnic groups in Ethiopia comprising approximately $6 \%$ of total population of the country, and $85 \%$ of the population is living in the rural areas [11]. The regional state contains other ethnic groups such as Erob and Kunama, accounting about $5 \%$ of the state's population. Tigrigna is the mother tongue of Tigray, and it is official working language of the region. Based on 2007 census conducted by CSA, 95\% of Tigray people are Orthodox Christianity followers.

Erob (also called Saho) are indigenous people living in Tigray National Regional State and on the Eritrean side of the border. Erob Wereda is the district of Erob people in Eastern Tigray Zone. The mother tongue of Erob people is Saho, and "Geez" is the script. In Erob district, Tigrigna is the working language [12]. Christianity was introduced to the region as far back as the fourth century, and they are Christians either Orthodox or Catholics [13]. According to the Central Statistical Agency of Ethiopia (CSA), the population size of Erob was projected to be 29,374 in 2017 [11].

The survey was conducted in four districts of East Tigray Zone, Ethiopia. The Zone has nine districts, namely, Gulo Meheda-Wereda, Erob-Wereda, Saesi TsadambaWereda, Ganta Afeshum-Wereda, Hawuzen-Wereda, Kilte Awlalo-Wereda, Atsbi Wonberta-Wereda, Adigrat
/Town/-Wereda, and Wukro/Town/-Wereda [11]. From

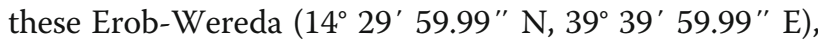

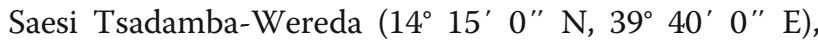
Atsbi Wonberta-Wereda (13 $\left.52^{\circ} 0^{\prime \prime} \mathrm{N}, 39^{\circ} 44^{\prime} 0^{\prime \prime} \mathrm{E}\right)$, and Adigrat/Town/-Wereda (14 $14^{\circ} 16^{\prime} 0^{\prime \prime} \mathrm{N}, 39^{\circ} 27^{\prime} 0^{\prime \prime}$ E) were selected (Fig. 1).

\section{Household selection and data presentation}

Consulting East Tigray Zonal Administrative Office, four districts were selected purposively considering their dependency on traditional foods and beverages. District administrative offices, peasant association leaders, district culture and tourism offices, and local elders were invited to suggest appropriate households. From a list of recommended households, 60 informants (15 from each district) were randomly selected using lottery method of sampling by assigning number, with each number corresponding to a subject. Then, they were recruited after obtaining their consent to participate in the study. For each traditional food or beverage, the informants were asked to list and explain the type of food and beverage they prepare at home, preparation method, procedures they follow, ingredients they add, preparation purpose, preparation frequency, shelf life, challenges, current status, and average Ethiopian Birr (ETB) they spent per event to prepare typical food or beverage.

The data were summarized using descriptive statistics and presented by percentages, frequency distribution, tables, charts, and graphs. All the analyses were done using SPSS Statistics for Windows, version 21 (IBM Corp., N.Y., USA).

\section{Results}

\section{Socio-demographic characteristics}

The age of respondents varied between 25 and 77 with a mean of $49.45 \pm 14.39$ years. All respondents were born in the study area. The minimum, maximum, and average years they lived in the study area were 25,77 , and 47.72 \pm 14.27 , respectively. There was no significant difference between age of the informants and number of years they lived in the study area $(\alpha=5 \%, 2$-tailed independent samples $t$ test, $t_{(118)}=0.355, P=0.723,95 \%$ CI $[-4.273$ to 6.140$]$ ). Table 1 shows the socio-demographic characteristics of respondents.

\section{Traditional foods/beverages prepared by the local community}

Totally, 13 typical traditional foods and five traditional beverages were listed by informants from the four districts of East Tigray: Erob eight (five traditional foods and three beverages), Saesi Tsadamba seven (four traditional foods and three beverages), Atsbi Wonberta 11 (seven traditional foods and four beverages), and Adigrat six (four traditional foods and two beverages). The listed 


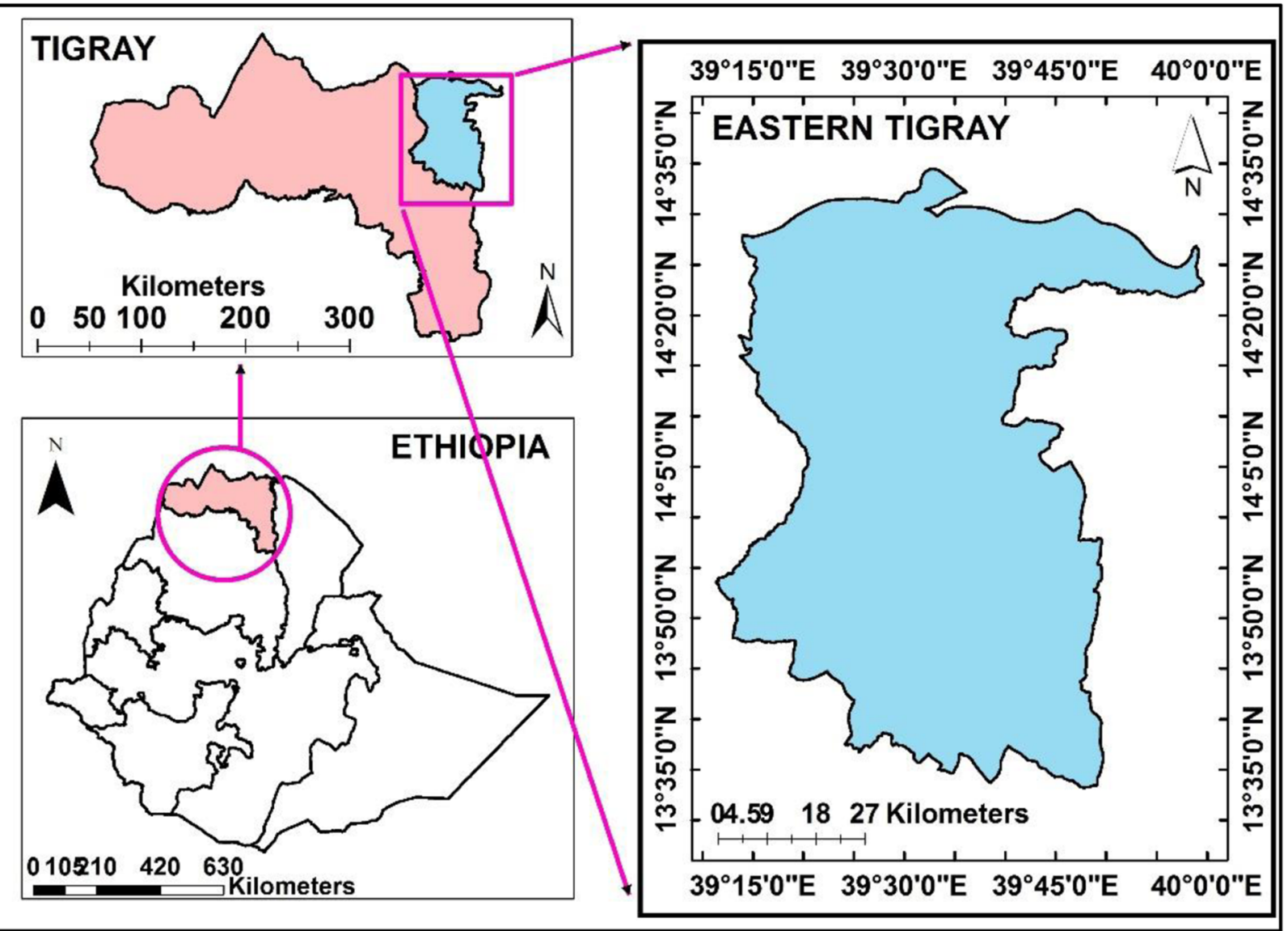

Fig. 1 Map of Tigray National Regional State of Ethiopia and Easter Tigray Zone

traditional foods and beverages in each district are presented in Table 2. Figure 2 shows the two typical fermented traditional foods called Ambasha and Ebist.

\section{Tihelo}

Informants notified Tihelo is a unique traditional food which women prepare from barley (Hordeum vulgare) flour and serve it by pinching (Fig. 3). They also stated a woman who pinches Tihelo shall ingest a pinch of it to announce the beginning of dining; no one is allowed to eat before she does this, but while pinching, she cannot eat; it is taboo. Tihelo is eaten using traditional woody fork called "Shenter." During group discussion session, informants proposed the following Tihelo preparation practices: barley pounding using woody mortar and pestle to remove chaff, wind winnowing, incubating in warm water for $1 \mathrm{~h}$, drying at room temperature for 12 $\mathrm{h}$, toasting with small amount of sands on a clay pan (Mitad), separate barley grains from sands, pounding by woody mortar and pestle to remove remaining chaff, wind winnowing, milling using traditional stone mill, sifting 2-3 times using fine sifter, make thick dough with cold water, kneading, pinching in small sizes, and serving to eat. Tihelo is served with tomato stew (particularly during fasting periods) or meats stew or butter during Lenten, and Elbet is another cultural stew condiment which is made from peas (Pisum sativum) or faba beans (Vicia faba).

\section{Giezm}

Informants stated Giezm is prepared from meat of sheep/goat and table salt. They also proposed the following practices to prepare Giezm: selecting soft meat of sheep/goat, chopping in small sizes, wash the colon (small bowel) of sheep/goat by inverting, mix table salt with chopped meat, put the mixture in the tube of washed small bowel, cook by steaming in boiling water, and serve.

\section{Gaa't}

Informants made Gaa't (porridge) from barley (Hordeum vulgare) or wheat (Triticum aestivum) flour by slowly adding the flour in to boiling water (Fig. 4). They differentiate cooked Gaa't by its loss of water by evaporation, color change, and mixture thickness, and its hardness to stir. Melt butter (or cooking oil) mixed with 
Table 1 Gender, religion, ethnicity, occupation, and education of respondents by their district

\begin{tabular}{|c|c|c|c|c|c|c|c|c|c|}
\hline & & \multicolumn{8}{|c|}{ District } \\
\hline & & \multicolumn{2}{|c|}{ Erob } & \multicolumn{2}{|c|}{ Adigrat } & \multicolumn{2}{|c|}{ Saesi Tsadamba } & \multicolumn{2}{|c|}{ Atsbi Wonberta } \\
\hline & & $N$ & $\%$ & $N$ & $\%$ & $N$ & $\%$ & $N$ & $\%$ \\
\hline \multirow[t]{3}{*}{ Gender } & Male & 6 & 40 & 8 & 53.3 & 2 & 13.3 & 7 & 46.7 \\
\hline & Female & 9 & 60 & 7 & 46.7 & 13 & 86.7 & 8 & 53.3 \\
\hline & Total & 15 & 100 & 15 & 100 & 15 & 100 & 15 & 100 \\
\hline \multirow[t]{3}{*}{ Religion } & Orthodox & 3 & 20 & 14 & 93.3 & 15 & 100 & 15 & 100 \\
\hline & Catholic & 12 & 80 & 1 & 6.7 & - & - & - & - \\
\hline & Total & 15 & 100 & 15 & 100 & 15 & 100 & 15 & 100 \\
\hline \multirow[t]{3}{*}{ Ethnicity } & Tigray & - & - & 15 & 100 & 15 & 100 & 15 & 100 \\
\hline & Erob & 15 & 100 & - & - & - & - & - & - \\
\hline & Total & 15 & 100 & 15 & 100 & 15 & 100 & 15 & 100 \\
\hline \multirow[t]{4}{*}{ Occupation } & Farmer & 11 & 73.3 & 7 & 46.7 & 9 & 60 & 13 & 86.7 \\
\hline & Trader & 1 & 6.7 & 5 & 33.3 & 4 & 26.7 & - & - \\
\hline & Employee & 3 & 20 & 3 & 20 & 2 & 13.3 & 2 & 13.3 \\
\hline & Total & 15 & 100 & 15 & 100 & 15 & 100 & 15 & 100 \\
\hline \multirow[t]{6}{*}{ Education } & Illiterate & 3 & 20 & - & - & 4 & 26.7 & 4 & 26.7 \\
\hline & $1-4$ & 3 & 20 & 5 & 33.3 & 1 & 6.7 & 4 & 26.7 \\
\hline & $5-8$ & 7 & 46.7 & 6 & 40 & 5 & 33.3 & 2 & 13.3 \\
\hline & $9-12$ & 2 & 13.3 & 1 & 6.7 & 2 & 13.3 & 2 & 13.3 \\
\hline & Above 12 & - & - & 3 & 20 & 3 & 20 & 3 & 20 \\
\hline & Total & 15 & 100 & 15 & 100 & 15 & 100 & 15 & 100 \\
\hline
\end{tabular}

$N$ number of respondents from district, \% percent of respondents within district, - no value

Table 2 List of traditional foods and beverages by district

\begin{tabular}{|c|c|c|c|c|c|}
\hline & \multirow{2}{*}{$\begin{array}{l}\text { Local name of traditional } \\
\text { food/beverage }\end{array}$} & \multicolumn{4}{|c|}{ Districts } \\
\hline & & Erob & Saesi Tsadamba & Atsbi Wonberta & Adigrat \\
\hline \multirow[t]{13}{*}{ Food } & Ambasha & - & Yes & Yes & - \\
\hline & Beso & - & - & Yes & - \\
\hline & Birkuta & Yes & - & - & - \\
\hline & Dageha & Yes & - & - & - \\
\hline & Ebist & - & Yes & - & - \\
\hline & Gaa't & - & - & Yes & Yes \\
\hline & Giezm & Yes & Yes & - & Yes \\
\hline & Hilumayt & Yes & - & - & - \\
\hline & Sola & - & - & - & Yes \\
\hline & Tihelo & Yes & Yes & Yes & Yes \\
\hline & Tiqtiqo & - & - & Yes & - \\
\hline & Torosho & - & - & Yes & - \\
\hline & Zikizuko & - & - & Yes & - \\
\hline \multirow[t]{5}{*}{ Beverage } & Abaekah/Habesh & - & Yes & - & - \\
\hline & Duqua & - & - & Yes & - \\
\hline & Suwa & Yes & Yes & Yes & Yes \\
\hline & Mes & Yes & Yes & Yes & Yes \\
\hline & Tahetah & Yes & - & Yes & - \\
\hline
\end{tabular}




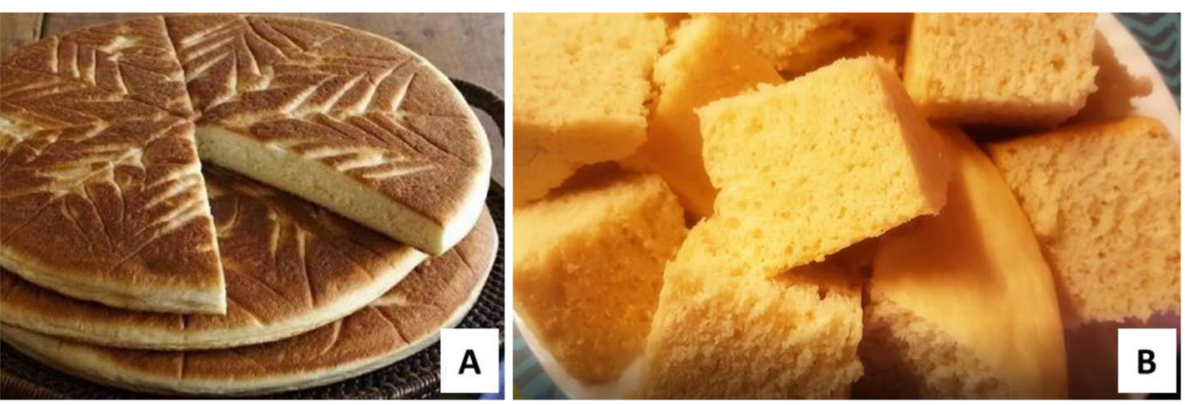

Fig. 2 a Ambasha, relatively a thin circular bread. It is triangularly sliced to serve. $\mathbf{b}$ Ebist, a thick celebrity bread. Ebist is sliced into cubes by elder after praying in a religious way. Both Ambasha and Ebist are fermented traditional foods which are commonly prepared from wheat flour (screen capture, https://www.youtube.com/watch?v=mrlRDcUDACQ)

pepper powder is used as a condiment of Gaa't; the butter or oil is put in the middle of Gaa't by molding it using spoon back. The following brief Gaa't preparation practices were proposed by informants: barley or wheat pounding using woody mortar and pestle to remove chaff, wind winnowing, slightly toasting (if it is barley), pounding by woody mortar and pestle to remove chaff (if it is barley), wind winnowing (if it is barley), milling to make flour, boil water, cooking on stove (by mixing hot water, flour, and table salt), stir continuously for 30 to $60 \mathrm{~min}$, take off from the stove and wait until the temperature comes down, transfer the cooked Gaa't from cooking pot in to bowl using woody scoop, and serve with butter. Usually, hot Gaa't is used to serve, and the amount of Gaa't to be prepared depends on the number of individuals to be served.

\section{Zikizuko}

Informants make Zikizuko from roughly ground barley (Hordeum vulgare). The coarser particles left on the mesh strainer after sifting are called Enfafo or Zikizuko, and it is eaten by mixing with boiled milk or warm water. Informants prepare Zikizuko in the following brief way: incubate barley grains in warm water for $3 \mathrm{~h}$, decant the water and keep overnight at room temperature, toast, slowly pound using woody mortar and pestle to remove chaff, wind winnowing, roughly grind using traditional stone mill, and sift using sieve; the remaining coarser on the sieve is called Enfafo, mix Enfafo with boiled milk or warm water for $10 \mathrm{~min}$, and serve it.

\section{Suwa}

Informants briefed that Suwa is one of the most common home-brewed alcoholic drink which is served at home during holidays (Fig. 5). They prepare Suwa usually from barley (Hordeum vulgare) or sorghum (Sorghum bicolor) and buckthorn (Rhamnus prinoides). In our group discussion session, they proposed the following brief recipe as a common to prepare Suwa: wash a barrel (traditional clay container called insera) 3-5 times using Grawa (Vernonia amygdalina), fumigating barrel by smoking weyra (Olea europaea subsp. Cuspidate) and/or tinjute (Otostegia integrifolia), mix buckthorn powder with water and keep at room temperature for 5

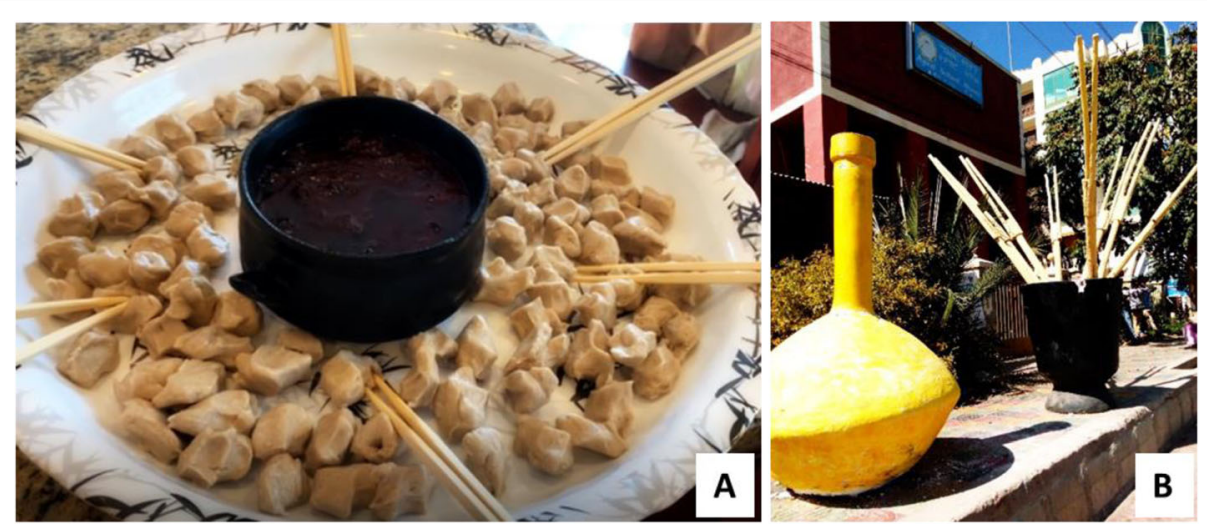

Fig. 3 a Pinched Tihelo on platter and stew in casserole. Tihelo is prepared from wheat flour and served with stew of tomato or meat. Usually, Elbet (not shown on this picture) is used to minimize the hot flavor of stew. b Statues of Mes, shenters (traditional woody forks), and a traditional tumbler of Suwa on the street of Adigrati city (November 2018) 


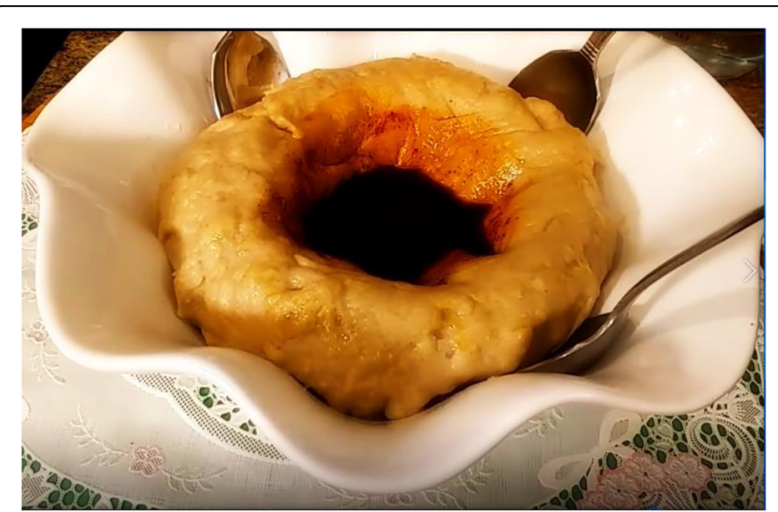

Fig. 4 Gaa't (porridge) with its condiment in a groove. Gaa't can be prepared from whole grain flours such as wheat, oat, barley, corn, or sorghum. Its condiment is commonly prepared by mixing ghee with pepper powder. (screen

capture, https://www.youtube.com/watch?v=NGicUBo90Cc)

days, pound barley using woody mortar and pestle to remove chaff, wind winnowing, milling using traditional stone mill, preparing dough, baking pancake on clay pan, milling the malt by traditional stone mill, mix (malt, buckthorn, and pancake) in the barrel, keep the mixture at room temperature for 4 days, dilute with water at the end of 4th day and firmly close the mouth of the barrel, open the barrel on 5th day, and serve it.

\section{Duqua}

Informants notified they prepare Duqua from barley (Hordeum vulgare) or sorghum (Sorghum bicolor) and buckthorn (Rhamnus prinoides). The proposed recipe to prepare Duqua was pounding barley using woody mortar and pestle to remove chaff, wind winnowing, milling using traditional stone mill, kneading with cold water to make dough, fumigating the barrel with smoke of weyra (Olea europaea subsp. Cuspidate), transfer the dough in to fumigated barrel, take out the dough on the 3rd day and fumigate the barrel (repeat this on every 3rd day until 12th day), bake traditional pancake on the 12th day, dry the pancake by basking on sunlight (this is called $A w u-$ nishte preparation), prepare Ankuro (pounding, wind winnowing, milling, toasting), boil water, incubating barley in boiling water for $2 \mathrm{~h}$, invert the container mouth for 9-10 $\mathrm{h}$ to completely remove the water, toast the barley, slowly pound using mortar and pestle, wind winnowing, milling using traditional stone mill, sifting using fine sieve, mix (Ankuro, powder of buckthorn, water, and malt) in a fumigated barrel, keep the mixture at room temperature for 7 days, mixing Awunishte and Ankuro (one hand Awunishte to two hand Ankuro), keep at room temperature for 3 days, dilute with cold water, and at the end of 10 days it will be ready to serve. The Difdif can stay for more than 6 months without deteriorating.

\section{Mes}

Based on informants' agreement during group discussion, Mes is a delicious drink that many households make at home to honor important events (Fig. 6). They remarked Mes preparation is simple, requiring honey and buckthorn powder. The whole process may take a month, ant its quality depends on the quality of honey and the experience of a person who prepares it. The proposed recipe was fumigating a barrel by smoking weyra (Olea europaea subsp. Cuspidate), dilute in a ratio of 1 $\mathrm{kg}$ honey to $2 \mathrm{~L}$ of water, stirring, keep at room temperature for 4 days, filter, add buckthorn powder and "tsedo" (bark of a tree, the name of this plant was claimed to be confidential. Only few informants use tsedo, and their Mes is preferable), keep at room temperature for 20 days, transfer into another fumigated barrel, add $1 \mathrm{~kg}$ honey (if needed), and serve it. Mes is typically served with a flask like a glass called Brille.
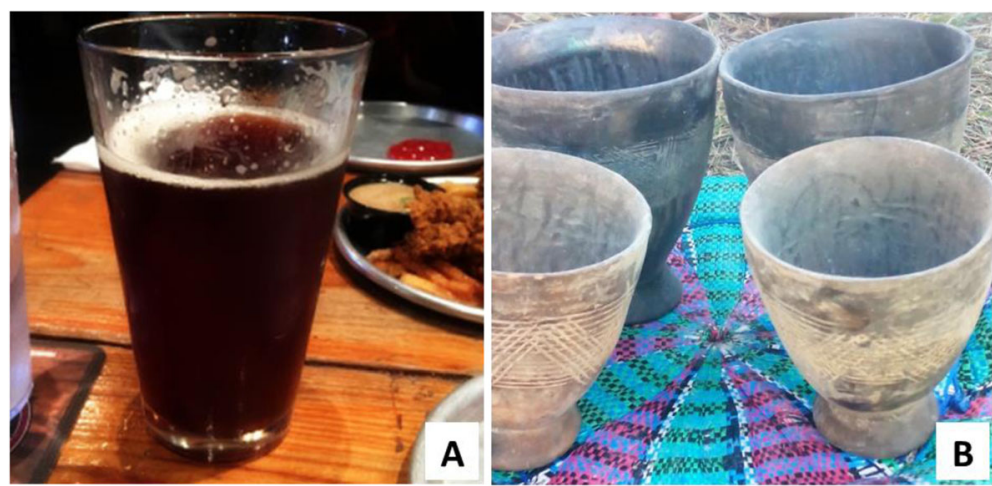

Fig. 5 a Suwa in tumbler glass. Urban areas of Ethiopia usually use tumbler glasses to drink Suwa (https://untappd.com). b Traditional beakers to serve Suwa. They are made from wood or clay. (Picture was taken consenting a respondent who possessed the heritage and resident of Adigrat city, 2018) 

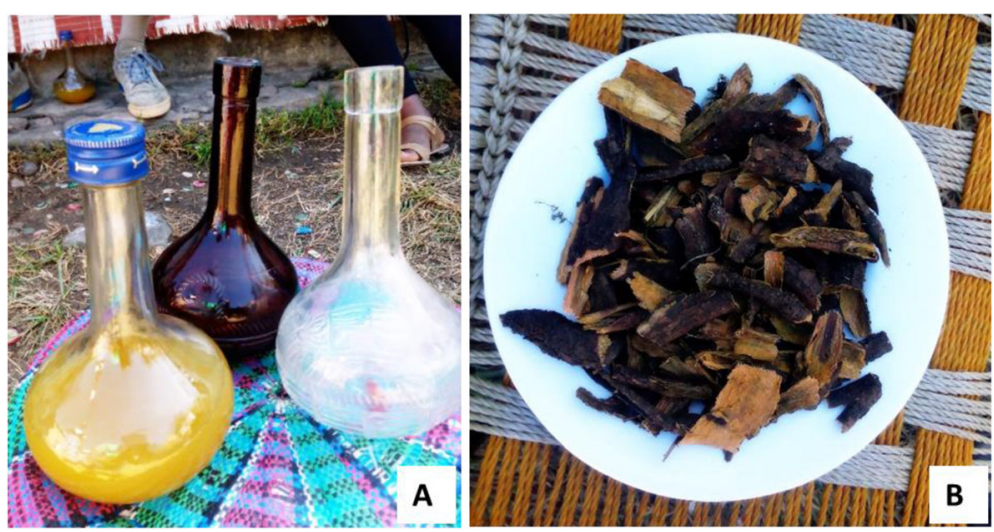

Fig. 6 a Mes and Brille. The dark-red Brille is used to honor elders or respected guest. b Tsedo, bark of a tree. The name of the plant was claimed to be confidential. Informants use tsedo to increase quality and durability of Mes, and it is favored by consumers. (Pictures were taken consenting a respondent who is a resident of Adigrat city, 2018)

\section{Habesh/Abaekah}

The respondents notified they prepare habesh from roasted barley and sugar. The proposed recipe to prepare habesh was wash barley with warm water, dry by basking on sunlight, roast on a traditional clay plate, milling using traditional stone mill, mix flour and water, remove supernatant after day one, mix thoroughly by stirring, transferring into large jar, add water, keep at room temperature for 6 days, add sugar on the 7 th day, then serve it.

\section{Status and sociocultural roles of traditional foods/ beverages}

From the total listed traditional foods, $46 \%$ were prepared for daily consumption or commercial purposes and $54 \%$ to celebrate events or to sell on the local

Table 3 Roles and status of traditional food/beverage preparation

\begin{tabular}{|c|c|c|c|c|c|c|c|}
\hline \multicolumn{2}{|c|}{ Traditional food/beverage } & \multirow{2}{*}{$\begin{array}{l}\begin{array}{l}\text { Purpose of } \\
\text { preparation }\end{array} \\
\text { DC/CP }\end{array}$} & \multirow{2}{*}{$\begin{array}{l}\text { Prepared by } \\
\text { F }\end{array}$} & \multirow{2}{*}{$\begin{array}{l}\text { Preparation rate } \\
\text { compared to past } \\
\text { Constant }\end{array}$} & \multirow{2}{*}{$\begin{array}{l}\text { Frequency of } \\
\text { preparation per year } \\
8\end{array}$} & \multirow{2}{*}{$\begin{array}{l}\text { Market affordability } \\
\text { Affordable }\end{array}$} & \multirow{2}{*}{$\begin{array}{l}\text { Who is allowed to } \\
\text { eat/drink? } \\
\text { All }\end{array}$} \\
\hline Food & Ambasha & & & & & & \\
\hline & Beso & DC & $\mathrm{F}$ & Constant & 6 & Affordable & All \\
\hline & Birkuta & DC & M & Decreasing & 3 & Affordable & All \\
\hline & Dageha & DC & $\mathrm{F}$ & Constant & 5 & Affordable & All \\
\hline & Ebist & CeP & $\mathrm{F}$ & Constant & 10 & Affordable & All \\
\hline & Gaa't & CeP & $\mathrm{F}$ & Constant & 8 & Affordable & All \\
\hline & Giezm & $\mathrm{CeP}$ & M & Decreasing & 4 & Pricy & All \\
\hline & Hilumayt & $\mathrm{CeP}$ & M & Decreasing & 4 & Pricy & All \\
\hline & Sola & $\mathrm{CeP}$ & M & Constant & 5 & Affordable & Adults \\
\hline & Tihelo & $\mathrm{CeP} / \mathrm{CP} / \mathrm{DC}$ & $\mathrm{F}$ & Constant & 8 & Affordable & All \\
\hline & Tiqtigo & $\mathrm{CeP}$ & $\mathrm{F}$ & Decreasing & 1 & Affordable & All \\
\hline & Torosho & DC & $\mathrm{F}$ & Decreasing & 2 & Affordable & All \\
\hline & Zikizuko & DC/CeP & $\mathrm{F}$ & Decreasing & 8 & Affordable & All \\
\hline \multirow[t]{5}{*}{ Beverage } & Habesh/Abaekah & $\mathrm{CeP} / \mathrm{CP}$ & $\mathrm{F}$ & Constant & 7 & Affordable & All \\
\hline & Duqua & $\mathrm{CeP} / \mathrm{CP}$ & $\mathrm{F}$ & Constant & 5 & Affordable & Adults \\
\hline & Suwa & $\mathrm{CeP} / \mathrm{CP}$ & $\mathrm{F}$ & Constant & 8 & Affordable & Adults \\
\hline & Mes & $\mathrm{CeP} / \mathrm{CP}$ & $\mathrm{M} / \mathrm{F}$ & Decreasing & 6 & Pricy & Adults \\
\hline & Tahetah & $\mathrm{CeP}$ & $\mathrm{F}$ & Decreasing & 4 & Pricy & All \\
\hline
\end{tabular}

$C D$ for daily consumption, $C P$ commercial product, $C e P$ celebration purpose, $M$ male, $F$ female 
market. All the noted beverages were prepared either for ceremonial usage or domestic commercial purposes. Of the total listed product, $22 \%$ are prepared by male and consumed by adult. The maximum frequency of traditional food or beverage preparation at home in past depended on the cost of materials needed to prepare the product. The sociocultural roles and the current status of traditional food/beverage preparation are presented in Table 3.

The local community notified they prepare traditional food or beverage regularly following yearly coming ceremonial days like religious holidays. They explained they usually prepare both traditional food and beverage simultaneously and customarily during public holidays: Ethiopian New Year, Meskel (an annual religious holiday of Ethiopian Orthodox church to commemorate the discovery of True Cross), Christmas (annual religious celebration, called Gena), Timkat (annual celebration of Epiphany), Fasika (Ethiopian Easter), Zikir (to remember Angels or Saints, for instance Hidar-12/November-21 to remember Saint Michael), on memorial days (for instance to memorize the day someone passed from family which is called Teskar), and birthdays; and they prepare occasionally to celebrate events including wedding, funeral, graduation, and when they host respected guest. Comparison of the popularity of traditional food or beverage within the district is shown in Figs. 7 and 8, respectively.

\section{Constraints of traditional food/beverage preparation}

Informants claimed inflation is the main determinant factor to frequently prepare traditional food or beverage at home. They noted preparation of Giezm, Hilumayt, Mes, and Tahetah was decreased in last year, due to unaffordability of the price of animal meat sources and honey in the local market. They also notified preparation of Tiqtiqo, Torosho, Zikizuko, and Birkuta is decreasing through time because of urbanization, seeing as uncivilized, benefiting modernization, and introduction new religion. Figure 9 shows the relationships among the amount of money needed per event to prepare food/ beverage, the minimum frequency of preparation in the past year, and the grade given by informants based on its popularity in the local community ( 10 for the most popular food or beverage).

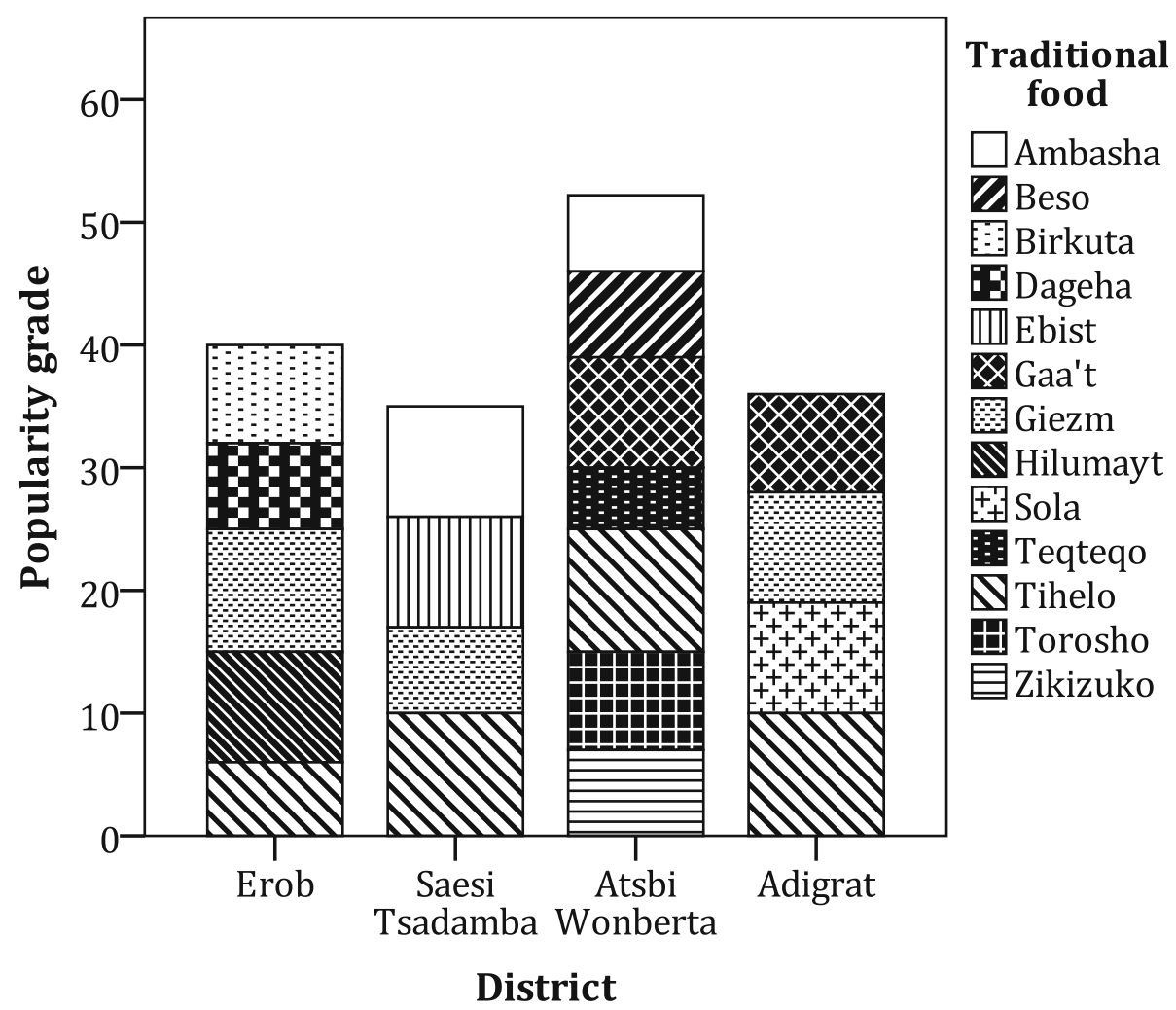

Fig. 7 Stacked bar chart representation of traditional food's popularity by district. Popularity of a food was rated by respondents assigning 10 for the most popular food. Cultural and social values were the main criteria that the respondents used to rank the food besides its economic and nutritional benefits. In Erob district, Giezm was ranked as the most popular traditional food of Erob ethnic group. In Saesi Tsadamba, Atsbi Wonberta, and Adigrat districts, Tihelo was ranked as the most popular traditional food of the community 


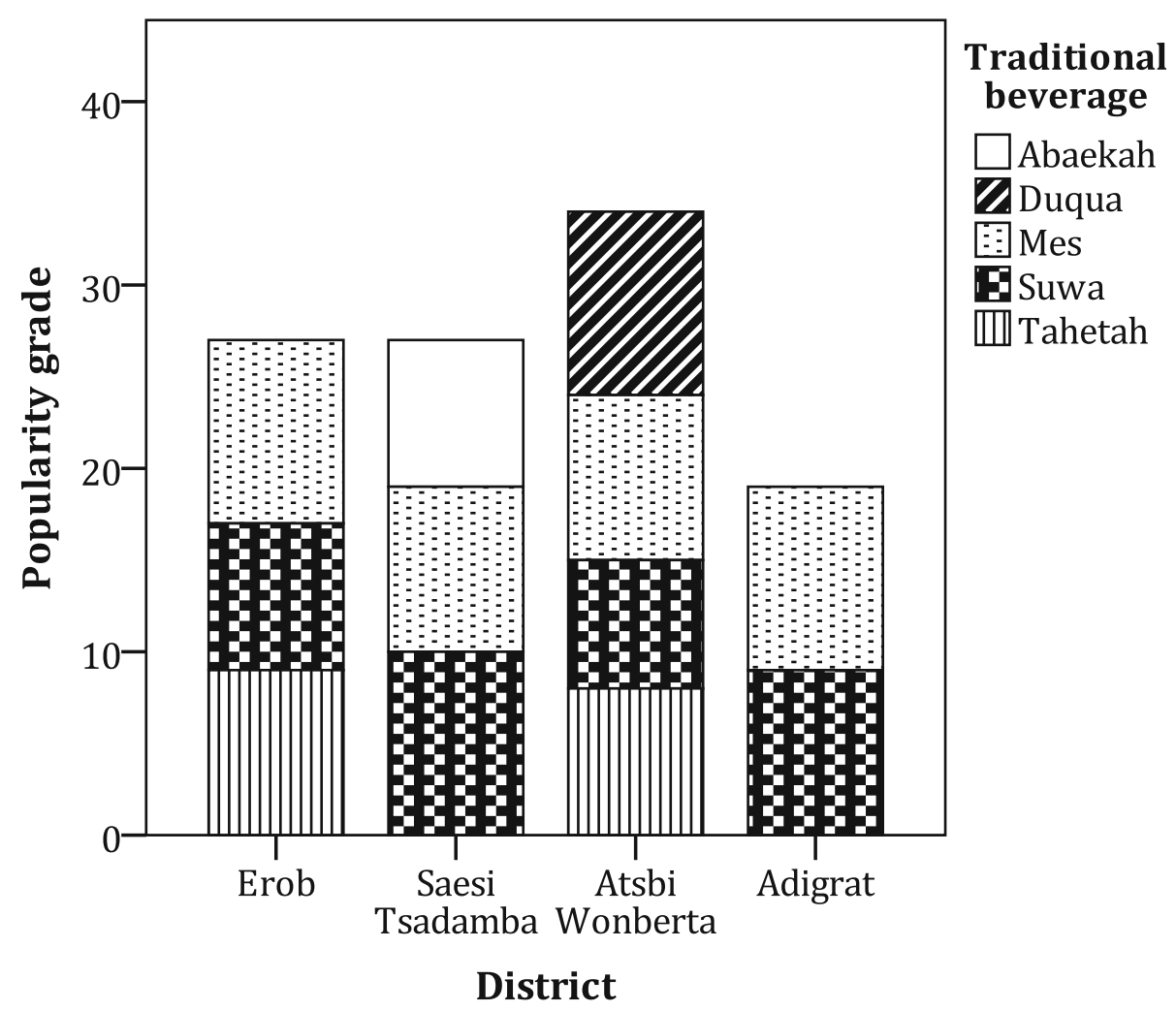

Fig. 8 Stacked bar chart representation of traditional beverage's popularity by district. Popularity of a beverage was ranked by respondents assigning 10 for the most popular beverage. Cultural and social values were the main criteria that the respondents used to rate the beverage besides its economic and nutritional benefits. Mes was ranked as popular beverage in the four districts

\section{Discussion}

The results of this survey come up with a list of distinctive traditional foods and beverages with their associated community knowledge which are suggested to be typical to the cultural values of the local people in East Tigray Zone (in particular the four districts: Erob-Wereda, Saesi Tsadamba-Wereda, Atsbi Wonberta-Wereda, and Adigrat/Town/-Wereda) of Tigray Regional State of Ethiopia.

With their condiments, Giezm, Hilumayt, Gaa't (porridge), Tihelo, Beso (roasted barley flour), Tiqtiqo (boiled wheat, corn, or beans), Torosho (thin bread), and Birkuta (thin dry bread) are non-fermented traditional foods. They are prepared from cereal crops except Giezm and Hilumayt which are meaty foods. Ebist (thick celebrity bread) and Ambasha (thin pancake-like bread) are popular fermented wheat flour breads. Abaekah (low alcoholic beverage), Duqua (unfiltered homemade beer), Suwa (filtered homemade beer), and Mes (honey wine) are fermented alcoholic beverages; however, Tahetah is non-fermented homemade honey drink. The community uses salting, drying, boiling, roasting, frying, baking, cooking, fermenting, or combinations of these to prepare the foods or beverages. Although the frequency of preparation per year is decreasing, due to socioeconomic issues, the dishes and beverages are regularly prepared following yearly or monthly coming ceremonial days such as religious holidays or occasional cases (e.g., to honor guests).

Tigray is a well-known region of Ethiopia by its diversity of culture with distinctive recipes to prepare foods and beverages which are native to the local community. Archaeological evidences from this region suggest food producing societies were living in the area before the third millennia $\mathrm{BC}$, and the geomorphologic, palynological, and archaeological studies in the region also provide the dynamic relationships between human and environment during the Holocene [5]. This survey highlights that traditional food or beverage preparation practice is the most important part of the local community, and most likely strongly linked to their cultural identity. Such practices describe the stances, identities, values, norms, and believe of the community by creating a unique atmosphere of familiarity, togetherness, belongingness, and comradeship $[14,15]$. The cultural dishes and drinks establish a ground to exchange experiences and beliefs which are the basis of a cohesive community; they are considered to be nutritious and safe to address food security issues $[14,16]$.

Although the knowledge of a special skill is limited to the local community, preparation and consumption of 


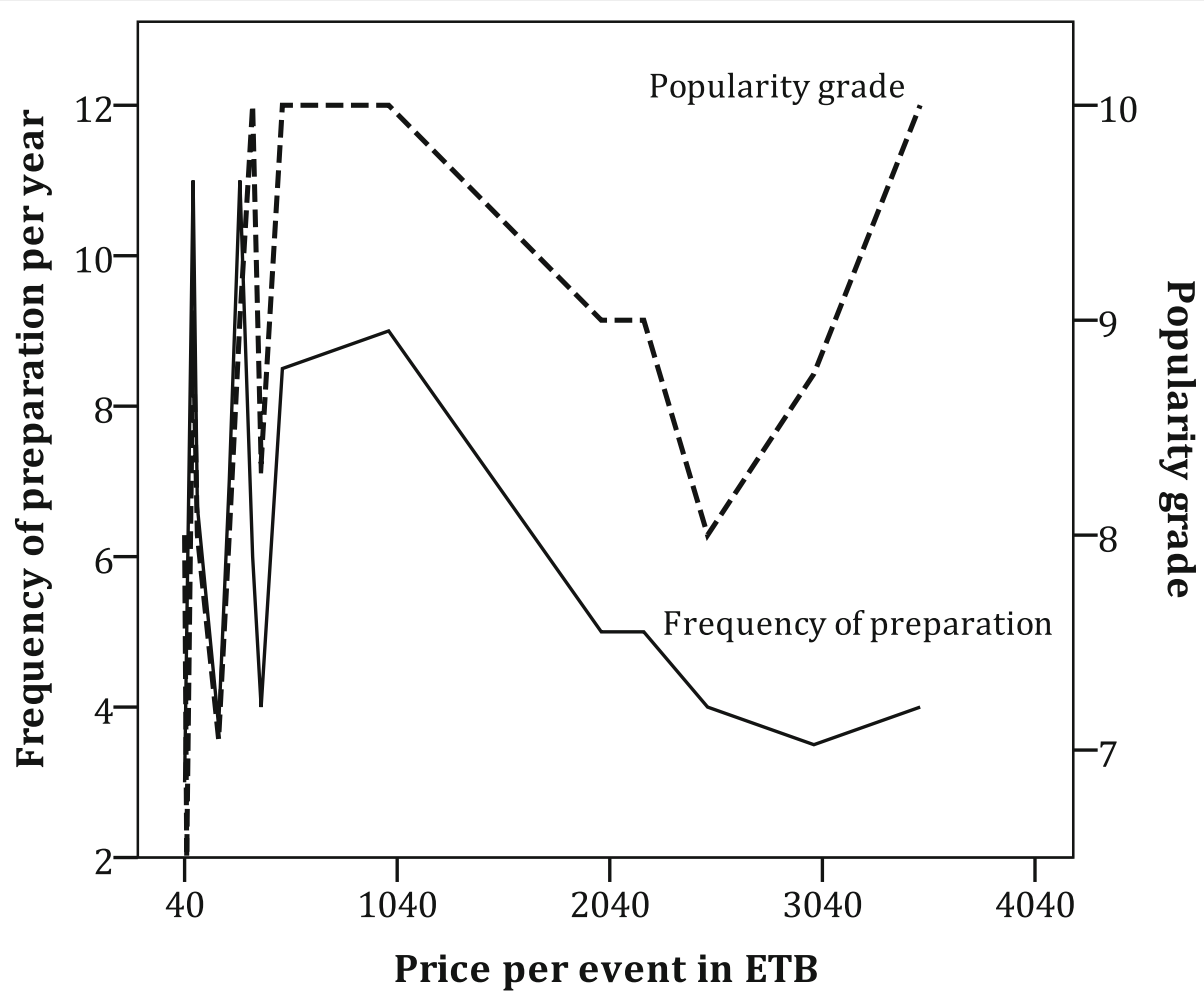

Fig. 9 A plot representation of the relationships among preparation frequency, price, and popularity grade of foods and beverages. Popularity of a food or beverage was ranked by respondents assigning 10 for the most popular food or beverage. Cultural and social values were the main criteria that the respondents used to rank the food or beverage besides its economic and nutritional benefits. The amount of money (Ethiopian Birr, ETB) needed to prepare a particular food or beverage for one event was estimated by respondents based on the price of materials in the local market in November 20018. The rate for the USD/ETB currency conversion was 27.87 ETB for 1 USD at the time of data collection. Frequency of preparation refers to the minimum frequency a particular food or beverage was prepared at home in a past year

traditional dishes/beverages such as Gaa't, Beso, Ebist, Tiqtiqo, Torosho, Abaekah-Habesh, Duqua, Suwa, and Mes were also reported in different parts of Ethiopia [7, 17-19]. These dishes/drinks including their practices have sociocultural, nutritional, medical, and economic significances. Some of the noted practices can be the best experience to solve communities' problem, especially the poor. For example, a field experience analysis reported that Afar pastoralists prepare Birkuta from corn flour by baking on a flat stone set on firewood. They use it as a survival food for a long journey or for a looming drought because it can be kept for a long time if made with butter [20]. Besso is a popular public food that people carry with them (commonly called "Sinq") to ensure food security during long-distance travel or depart from family. Others like Gaa't, Tihelo, and Zikizuko are well known for their medicinal health benefits including remedy for antiinflammatory, postpartum diet, and to treat fracture $[6,7]$. Additionally, the foods/beverages such as Ambasha, Tihelo, Duqua, Suwa, Mes, and Tahetah are commercially available in the local market, and selling them is a source of income for some community members not only in East Tigray but also in other parts of Ethiopia [18].
Unfortunately, economic problems, urbanization, benefiting modernization, seeing as a primitive method, and the introduction of new religions are posing pressure on the preparation of the dishes or beverages. Particularly, the economic problem is becoming a major determinant factor to frequently prepare the dishes at home. Say, preparing Giezm, Hilumayt, and Mes was becoming challenging in past year in Erob district, as animal meat sources and honey are expensive in the local market. These and the absence of an attempt to modernize the process may lead to loss of traditional practices from cultural landscapes $[9,21]$.

On the other perspective, traditional food or beverage processing under primitive conditions is tedious and labor-intensive, consuming much energy and time with low yield and poor quality [22]. It imposes negative impacts on biodiversity due to deforestation for fuel and cultivation. However, improving the practices through modification and transformation may enhance biodiversity conservation, food security, and economic development. In Ethiopia, the effort to optimize the knowledge in modern technology is very limited: except attempts on Injera and Mes. The American Brotherhood Winery 
produces and distributes Ethiopian organic honey wine (called Sheba Tej) using indigenous knowledge of Ethiopian women, and it is one of America's favorite Ethiopian honey wine [23]. Like Mes, Ethiopia has immense indigenous knowledge associated with traditional fermented or non-fermented food/beverage preparation which can be upgraded in technology to enhance production efficiency, food security, and to achieve sustainable development goals. For instance, Suwa can be a potential traditional beverage to commercialize in modern beverage industries. It has almost similar sugar and acidity content to that of modern beers [24]. Suwa is commonly prepared from buckthorn (Rhamnus prinoides) and malted barley (Hordeum vulgars) having many alternative crops: wheat (Triticum aestivum), maize (Zea mays), millet (Panicum miliaceum), sorghum (Sorghum bicolor), teff (Eragrostis tef), and rice (Oryza sativa) giving good opportunity to produce in quality and quantity [25]. Generally, advancing the culinary art in modern technology for global healthy diet and inspiring their commercialization in the global market help to address food security, public health, and biodiversity issues.

To conclude, the results of this survey publicize typical traditional foods, beverages, and practices which have cultural, social, and economic roles for the local community of East Tigray. The foods and beverages are potentially applicable in modern food or beverage industries. However, they are underutilized resources in Ethiopia may be due to lack of awareness, negligence, and/or undermining. Therefore, further detail studies are needed to advance the processes in modern technology.

\section{Acknowledgements}

We gratefully acknowledge all those who helped us in many ways to accomplish data collection and analysis successfully.

\section{Authors' contributions}

N.S.T. and G.F.B. conceived and designed the study. N.S.T., T.B.H., and A.A.H. performed the computations and verified the analytical methods. All authors discussed the results and contributed to the final manuscript. The manuscript has not been submitted, in whole or in part, to other journals. The author(s) read and approved the final manuscript.

\section{Funding}

The field work of this study was financed by Ethiopian Biodiversity Institute. The authors received no financial support for study design, data analysis, decision to publication, or preparation of the manuscript.

\section{Availability of data and materials}

The datasets associated with this article can be accessed from the corresponding author on reasonable request.

\section{Competing interests}

We, the authors, declare that we have no conflict of interest on the research, authorship, and publication of this article.
Received: 6 January 2020 Accepted: 27 April 2020

Published online: 14 May 2020

\section{References}

1. Dutfield G. TRIPS-related aspects of traditional knowledge. Case W Res J Int L. 2001;33:233-75.

2. Ayaa D, Waswa F. Role of indigenous knowledge systems in the conservation of the bio-physical environment among the Teso community in Busia County-Kenya. Afr J Env Sc Technol. 2016;10: 467-75.

3. Anteneh T, Tetemke M, Mogessie A. Antagonism of lactic acid bacteria against foodborne pathogens during fermentation and storage of borde and shamita, traditional Ethiopian fermented beverages. Int Food Res J. 2011;18:1189-94.

4. Hall C, Sharples L. Food and wine festivals and events around the world: development, management and markets. Routledge 2008. ISBN: 0750683805, 9780750683807.

5. Bard KA, Coltorti M, DiBlasi MC, Dramis F, Fattovich R. The environmental history of Tigray (Northern Ethiopia) in the middle and late Holocene: a preliminary outline. Afr Archaeol Rev. 2000;17:65-86.

6. Kifleyesus A. The construction of Ethiopian national cuisine [Internet]. Asmara (Eritrea): University of Asmara; 2007. http://www.ethnorema.it/pdf/ numero\%202/ABBEBE\%20 KIFLEYESUS\%20-\%20The\%20Construction\%2 0of\%20Ethiopian\%20National\%20 Cuisine.pdf.

7. Mohammed J, Seleshi S, Nega F, Lee M. Revisit to Ethiopian traditional barley-based food. J Ethn Foods. 2016:3:135-41.

8. Lyons D. Integrating African cuisines: rural cuisine and identity in Tigray, highland Ethiopia. J Soc Archaeol. 2007;7:346-71.

9. Lee M, Regu M, Seleshe S. Uniqueness of Ethiopian traditional alcoholic beverage of plant origin, tella. J Ethn Foods. 2015;2:110-4.

10. Pathak M, Bharati K. Growing visibility and impact of Indian Journal of Traditional Knowledge. Indian J Tradit Knowl. 2018;17:407-13.

11. Central Statistical Agency. Population projection of Ethiopia for all regions at wereda level from 2014 - 2017. Addis Ababa (Ethiopia): Federal Democratic Republic of Ethiopia Central Statistical Agency; 2013.

12. Mamo $Y$. The protection of minority rights under regional constitutions in the Federal Democratic Republic of Ethiopia: the case of Tigray. Afr J Pol Sci Int Relat. 2017;11:249-57.

13. Tsegay BG. An ethno-historical survey of the Irob agri pastoralists of North Eastern Tigray (Ethiopia). [Internet] 2016. http://www.sahoarchive.org/wpcontent/uploads/2016/05/An-Ethno-Historical-Survey-of-the-Irob-AgriPastoralists-of-North-Eastern-Tigray-Ethiopia.pdf.

14. Prakash V, Martin-Belloso O, Keener L, Astley S, Braun S, McMahon H, Lelieveld $\mathrm{H}$. Regulating safety of traditional and ethnic foods: Elsevier, Academic Press; 2015

15. Fitrisia $D$, Sibarani $R$, Ritonga M. Traditional food in the perspective of culinary linguistics. International Journal of Multidisciplinary Research and Development. 2018:5:24-7.

16. Kuyu CG, Bereka TY. Review on contribution of indigenous food preparation and preservation techniques to attainment of food security in Ethiopian. Food Sci Nutr. 2019;8:3-15

17. Ashenafi M. The microbiology of Ethiopian foods and beverages: a review SINET:Ethiop J Sci. 2002;25:97-140.

18. Geleta N, Grausgruber H. Homemade products and socio-cultural values of wheat seed production in Ambo and Dandi Districts of West Central Ethiopia. Sci Technol Arts Res J. 2013;2:62-70.

19. Getachew T. A review on traditional fermented beverages of Ethiopian. J Nat Sci Res. 2015;5:94-102.

20. International Institute of Rural Reconstruction (IIRR). Food security in pastoralist areas of Ethiopia. International Institute of Rural Reconstruction: Nairobi, Kenya; 2004.

21. Potdar K, Namrata N, Sami A. Nature, culture and humans: Patterns and effects of urbanization in lesser Himalayan Mountainous historic urban landscape of Chamba, India. J Herit Manag. 2018;2:169-88.

22. Achi $\mathrm{O}$. The potential for upgrading traditional fermented foods through biotechnology. Afr J Biotechnol. 2005;4:375-80.

23. Tariku H. Ethiopian indigenous knowledge of traditional foods and beverages processing: needs for modern food processing technology and transformations. Institute of Technology, Bahir Dar University, Bahir Dar 2012; NCSTI-2012:66-77. 
24. Getaye A, Tesfaye D, Zerihun A, Melese F. Production, optimization and characterization of Ethiopian taraditional fermented beverage Tella from barley. J Emer Technol Innov Res. 2018;5:797-9.

25. Berhanu A. Microbial profile of Tella and the role of gesho (Rhamnus prinoides) as bittering and antimicrobial agent in traditional Tella (Beer) production. Int Food Res J. 2014;21:357-65.

\section{Publisher's Note}

Springer Nature remains neutral with regard to jurisdictional claims in published maps and institutional affiliations.

Ready to submit your research? Choose BMC and benefit from:

- fast, convenient online submission

- thorough peer review by experienced researchers in your field

- rapid publication on acceptance

- support for research data, including large and complex data types

- gold Open Access which fosters wider collaboration and increased citations

- maximum visibility for your research: over $100 \mathrm{M}$ website views per year

At BMC, research is always in progress.

Learn more biomedcentral.com/submissions 